\title{
岩盤の弾性波速度と地質
}

杉本 卓 司*

\section{Elastic Wave Velocities of Various Rocks in Japan}

By Takuji Sugimoto

\section{まえがき}

ここに述べる岩盤とは地表を被う第四紀未固結層を除 去し，更に風化土および風化帯などの表層風化物を取除 いた際に露出すると考光られる新鮮な岩盤のことであ る。

岩盤内学伝播する弾性波縱波速度（以下速度という） は弾性波探査法の確立発展に伴ない急速な進歩があり, ぼう大な測定資料が得られている。これらの測定值につ いては従来から地質単元との対比が個々に行なわれてき た。速度と地質との関係についての多数の資料を整理 し，地質学上より系統的に速度を検討することは地質学 の定量化の一つの有力な手段であると考号れる。ここ では岩盤速度について地質学との関係の上で殊に特徵あ る点について要約して述べることにする。速度值の統計 に当り，各地点の測定資料のうちから最頻值の速度をも って，その地点を代表する速度值とした。

\section{1. 各変成帯の速度}

わが国の主部広域変成地域は飛驒，三郡，領家一阿武 隈, 三波川という四つの変成带に大別されるが，なおこ の他に神居古潭変成带, 四万十川変成带, 丹沢変成带な どがある。

各变成帯の速度の平均と標準偏差は 図 1 に示すとお りである。図で明らかなように，阿武隈変成带が最も大 きな值を示している。領家一阿武隈变成帯として類似の 变成帯と考元られている領家帯变成岩類が阿武隈带变成 岩類に比して可成り低速度を示している点について，地 質構造発達史の上で更に検討する必要があると考光られ る。また，阿武隈変成带は領家変成带とは類似する点も 多いが，領家变成作用とは異質な低温高圧型の広域变成 作用を受けており，このような変成作用の異質な点が速 度值の差となって現われたものと考光られる。

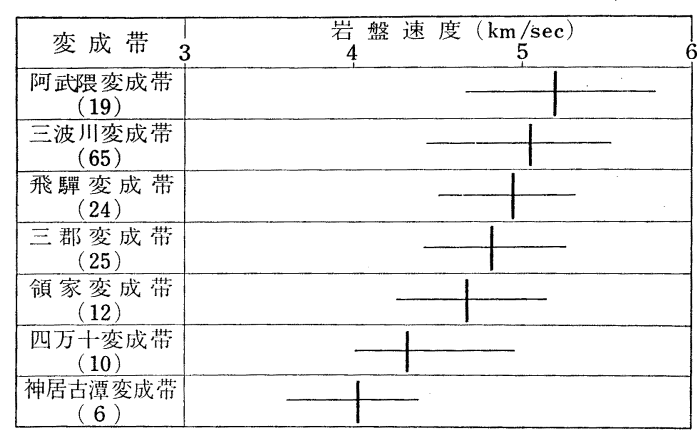

（）内は資料数，1は平均佃，一一は標潐偏差を示す

図 1 各变成帯の速度

中生代ないし第三紀の変成带と考光られている神居古 潭变成帯, 四万十川変成帯, および丹沢変成帯などの速 度は先中生代の変成帯の速度に比較して著しく低い值を 示している点が注目される。特に神居古潭変成带の速度

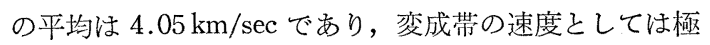
めて低い值である。

一般に速度は岩盤を構成する岩石の時代が古くなるに 従って大きくなると考光られているが, 変成带について も无程度同様なととが考えられよう。主として古生層 の変成岩から構成される三郡変成带の速度值の平均は $4.90 \mathrm{~km} / \mathrm{sec}$ であり，乙れを越光る平均速度值をもつ飛 驒変成帯, 三波川変成帯, および阿武隈変成帯などは日 本列島の基盤岩（後期古生代の本州地向斜の基盤岩）に 属する可能性が強いと考兄られる。三波川変成带の中で も点絞帯は速度值が大きく $(6.0 \mathrm{~km} / \mathrm{sec})$, 日本列島の 基盤岩に属する可能性は更に大きいものと考光られる。

\section{2. 花崗岩類の速度}

花崗岩類の速度は 図 2 に示すように，一般に古期の もの程大きな值を示し, 新期のもの程小さな值を示して いる。阿武隈古期花崗岩類や飛驒系の花崗岩類は大きな 速度值をもち，中生代末ないし第三紀にかけての貫入と

*日本物理探鉱株式会社 


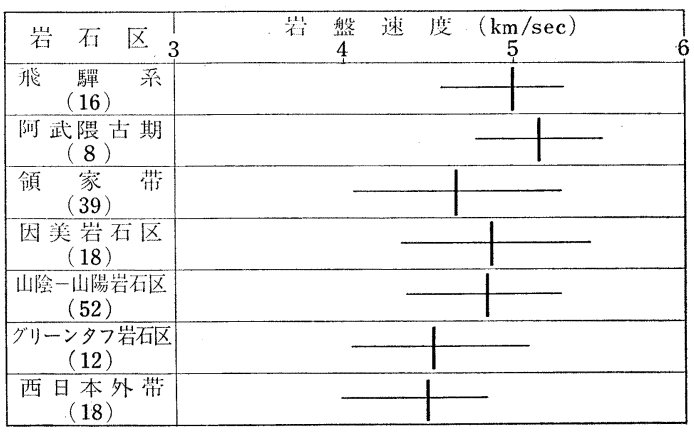

（）内は資料数，｜は平均值，一標準偏差を示す 図 2 花崗岩類の速度

考党られている日高岩石区，西南日本外帯，およびグリ ーンタフ岩石区の花崗岩類の速度値は小さい。

第三紀花崗岩類の速度に認められる特徴は先第三紀の 花崗岩類と同様な高速度をもつ地域もあるが，また低速、 度地域も可成りの分布を示している。これは第三紀の花 崗岩類が岩相の変化に富夕，特に周縁部では細粒閃緑 岩, 閃緑斑岩, 花崗斑岩, 石英斑岩などに, ときに流紋 岩，石英安山岩などに漸移し，熱水变質が著しく黄鉄鉱 に鉱染されているため子考光ら机，いわゆる火山〜深成 作用 (volcanoplutonism) によって形成された複合体であ ることによるものと考えられる。

\section{3. 各構造帯における変成岩類と花崗岩類の速度值の近 似性について}

飛驒帯，阿武隈带，日高带，および領家帯における変 成岩類の速度值の平均と, 花崗岩類の速度值の平均とは 表 1，および 図 3 に示すように極めて類似しているこ とが認められる。すなわち, 各構造帯における变成岩類 の速度值にはそれぞれ著しい差異が認められ，また花崗 岩類の速度值にもそれぞれ著しい差異が認められる。し かし，一つの構造带に属する変成岩と花商岩の速度值に は岩質の相違にもかかわらず，その平均值において全く 同一に近い值が得られている。

表 1 各構造帯に和ける变成岩類と花崗岩 類の速度值の近似性

\begin{tabular}{|c|c|c|c|c|}
\hline \multirow{2}{*}{ 構 } & \multirow{2}{*}{ 造 } & \multirow{2}{*}{ 带 } & \multicolumn{2}{|c|}{ 岩盤速度の平均 $(\mathrm{km} / \mathrm{sec})$} \\
\hline & & & 変成岩 類 & 花 崗 岩 類 \\
\hline 阿 & 武 隈 & 帯 & 5.26 & 5.21 \\
\hline 飛 & 驒 & 帯 & 4.98 & 5.00 \\
\hline 領 & 家 & 帯 & 4.77 & 4.74 \\
\hline 日 & 高 & 帯 & 4.58 & 4.63 \\
\hline
\end{tabular}

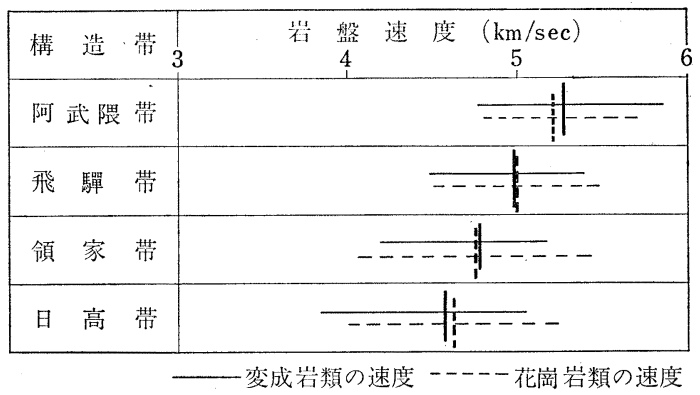

図 3 各構造帯に打ける変成岩類と花 崗岩類の速度の近似性

一つの構造帯における花崗岩類と变成岩類の類似性 は, その構造带に打ける広範な花崗岩化作用 (granitization）によって，花崗岩類が变成岩類の形成に密接な関 係をもつものと考光られる。以上に示す花南岩類の速度 值のうち, 飛驒帯では先シルリア紀の飛驒系花崗岩類の 速度值であり，阿武隈带抢よび領家帯では古期花崗岩類 の速度值であり，いずれも新期花崗岩類と变成岩類とで はその速度値に打いて類似性は認められない。

\section{4. 古生層の速度}

わが国の古生層を北上带, 足尾帯, 飛驒・丹波帯, 秩 父帯，および中国非变成带に大別して各帯の速度值を示 したものが 図 4 である。図より明らかなように，北上 帯の速度值が大きく，足尾带および飛驒・丹波帯の速度 值が小さい。このような速度の差は地層の堆積環境が大 きい要素を占めるものと考元られる。石炭紀後期〜二畕 紀中期における本州変動により本州地域が大規模に沈降 したが，足尾帯および飛驒・丹波帯はその地向斜のほぼ 中央部に位置し, 典型的な地向斜堆積物によって構成さ れている。こ礼対し北上带の二畳系は上昇地域に接し た变動陸棚ないしは島棚状の, 火山活動に乏しい地帯の

\begin{tabular}{|c|c|}
\hline 古 生 層 4 & 岩盤速度 $(\mathrm{km} / \mathrm{sec})$ \\
\hline 北 $\underset{(13)}{\text { 上 }}$ 带 & 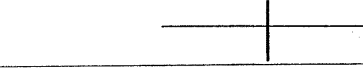 \\
\hline $\begin{array}{l}\text { 秩 } \begin{array}{c}\text { 父 } \\
(59)\end{array} \\
(59 \text { 带 }\end{array}$ & \\
\hline $\begin{array}{c}\text { 中国非変成带 } \\
(13)\end{array}$ & - \\
\hline $\begin{array}{c}\text { 飛驒 · 丹波带 } \\
(65)\end{array}$ & - \\
\hline $\begin{array}{ll}\text { 足 尾 } & \text { 带 } \\
(10)\end{array}$ & 1 \\
\hline
\end{tabular}

（）内は資料数，1は平均值，一一標準偏差を示す 図 4 古生層各带の速度 
堆積物で，いわゆる劣地向斜帯に相当する。典型的な地 向斜地域では堆積物に占める粘板岩の割合が大きく，そ の速度が著しく低い $(4.18 \mathrm{~km} / \mathrm{sec})$ 点が特徴とされ，平 均速度の值が低下する結果になったものと考えられる。

\section{5. 中生層の速度}

中生代における地質区は堆積環境にもとづいて，大洋 側の地向斜堆積地域と，本州・四国・九州の主部を占め る盆地状堆積地域に大別される。前者は四万十区，日高 区，北上外縁带と呼ばれ，後者は一括して本州区と称せ られる。

中生層の速度值は 図 5 に示すように, 本州区の中で ほ速度の平均が内側, 中軸部, 外側ともに $4.2 \sim 4.3 \mathrm{~km} /$ sec の值をもら大きな差は認められないが，大洋側の地 向斜堆積地域では，四万十区の速度の平均が $4.4 \mathrm{~km} / \mathrm{sec}$

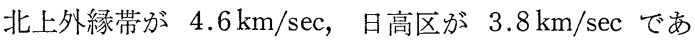
り，可成りの速度差が認められる。特に，北上外縁带の 岩石は日高区のものとある程度類似し, 砂岩, 粘板岩, チャート,および輝緑凝灰岩などより構成されているが， 速度值の上では大きな差が認められる。

古生層の速度と堆積環境との関係にみられるように， 中生層においても大洋側の地向斜堆積地域では一般に速 度值が大きく, 盆地状地向斜堆積地域では一般に速度值 が小さい。しかし，北海道の日高区の中生層は大洋側の 地向斜堆積地域とされているが著しく低速度を示してい る。あるいは日高地向斜は大洋側の地向斜よりもむしろ 盆地状地向斜の性質をより強くもつものとも考えられ， 今後更に検討を要する問題である。

\begin{tabular}{|c|c|}
\hline 中 生 層 & 岩盤速度 $(\mathrm{km} / \mathrm{sec})$ \\
\hline 日 $\begin{array}{c}\text { 高 } \\
(32)\end{array}$ & ] \\
\hline $\begin{array}{c}\text { 本州区内側 } \\
(32)\end{array}$ & 1 \\
\hline $\begin{array}{c}\text { 本州区中軸部 } \\
\text { (11) }\end{array}$ & \\
\hline $\begin{array}{c}\text { 本州区外側 } \\
(19)\end{array}$ & 1 \\
\hline 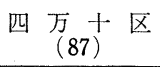 & \\
\hline
\end{tabular}

（）内は資料数，|は平均值，一標準偏差を示す 図 5 中生層各区の速度

\section{6. 古第三紀層の速度}

古第三紀の堆積岩は層相によって大きく 2 つのタイ゚ にわけられる。1つは四万十区によって代表され，純海

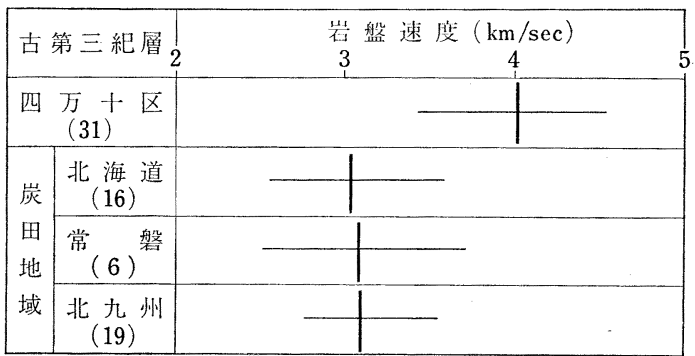

（）内は資料数，1は平均值，一標準偏差を示す

図 6 古第三紀層の速度

成相からなり，1つは北海道，九州，および本州の炭田 地域によって代表されるものであって，炭層を挾む海成 ・非海成相からなるものである。

図 6 に示すように四万十区の古第三系速度の平均は $4.0 \mathrm{~km} / \mathrm{sec}$ であり, 同じ四万十区の中生層の速度に比 較して可成り低速度であることが認められる。

炭田地域の古第三系速度の平均は $3.1 \mathrm{~km} / \mathrm{sec}$ であり, 四万十区の古第三系に比較すれば，更に著しく低い值と なっている。四万十区の堆積岩の速度值が大きいのは, 堆積環境が大洋側の地向斜をなし純海成相からなるとい うことが大きな要素を占めるものと考えられる。これに 対し, 炭田地域の速度值が小さいのは, その堆積環境が 内湾部の浅海底であったためであると考えられる。

\section{7. 新第三紀層の速度}

新第三系は内帯と外带の 2 つの特徵ある型にわけるこ とができる。内帯は火山物質を表としたグリーンタフ地 域に相当し，外帯注非火山性の物質を主とし，非グリー ンタフ地域に相当する。ここでは非グリーンタフ地域の 堆積岩の速度につき時代別に検討することにする。

図 7 に示すように中新統下部および中新統中部の速 度值の平均はそれぞれ $2.46 \mathrm{~km} / \mathrm{sec}$ おび $2.45 \mathrm{~km} / \mathrm{sec}$ であり, 殆えど差異が認められない。中新統上部の速度 值の平均は $2.21 \mathrm{~km} / \mathrm{sec}$ でやや小さな值となっており, 更に鮮新統では $1.99 \mathrm{~km} / \mathrm{sec}$ となり，可成り小さい值と なっている。このように堆積岩の年代が新しくなるに従 って速度の低下が認められる点は古生層および中生層の 堆積岩にも認められる点である。

以上の各統の速度の平均には宮崎層群と熊野層群を除 いて計算してある。図 7 に示すように宮崎層群および 熊野層群は新第三紀の堆積岩としては可成り大きな速度 值をもっている。これら両層群は四万十帯中に半盆状を なして分布し，それぞれ古第三系の日南層群および车婁 層群と斜交不整合をなす。このように四万十帯の古第三 

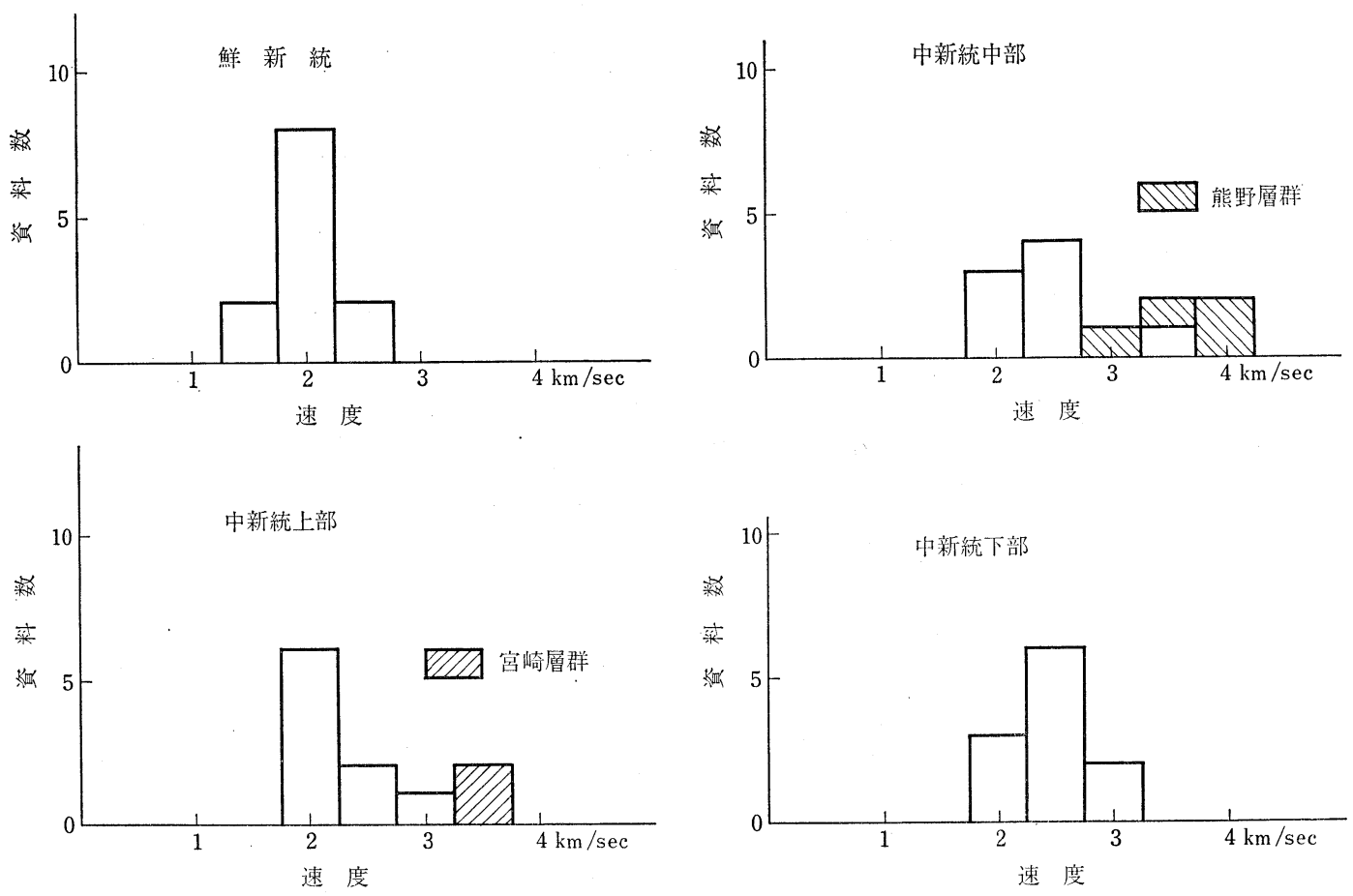

図 7 新第三紀層（非グリーンタフ地域）の速度

紀と中新世前期との間には造構時階があったが，宮崎層 群および熊野層群が新第三紀層の速度值として可成り大 きい值をもつことは四万十区の堆積環境が引続いて新第 三紀にも及えだもので, 堆積環境に大きな変化がなかっ たものと考えられる。

\section{まとめ}

以上に述べたことについて更に要約すれば次のとおり である。

同一構造帯に属する变成岩類と花崗岩類との速度值が ほぼ一致することは，深成作用と変成作用が進み岩相の 変化が著しくなっても，速度とのものには増減が殆んど 認められないということであり, 各構造帯は深成岩類, 变成岩類，あるいは堆積岩類と合せて一つの独立したブ ロックを形成するということができよう。北上および阿 武隈構造帯の速度は著しく高い点が特徴であり, 北海道 の日高および神居古潭構造帯の速度は著しく低い点が特 徵である。各構造帯には独自の速度が認められるが，こ の速度の差がどのような機構によって生じたものである か更に検討を要する問題である。

堆積岩類の速度はその堆積環境によって著しく変化す ると考えられる。一般に大洋側の地向斜堆積地域では速 度值が大きく，盈地状堆積地域では速度值がふさい点が
認められる。このような堆積環境によってどのように速 度が変っているかについては, 更に堆積岩生成後の地殼 変動との関連において十分な究明がなされなければなら ない。

\section{参 考 文 献}

1）島津康男 (1968): 地質学と地球物理学, 日本の地 質学

2）市川浩一郎・藤田至則・島津光夫（1970）：日本列 島地質構造発達史, 築地書館

3）湊正雄・井尻正二 (1969): 日本列島, 岩波書店

4) 柴田秀賢 (1968)：日本岩石誌 I, II, III, IV, 朝倉書 店

5）生出慶司 - 折本左千夫 (1966)：Volcano-Plutonic Complex としての Tertiary Granitoids, 東北日本の グリーンタフ変動（地団研専報 12）

6）鈴木淑夫 (1958)：北上山地の酸性深成岩類, 鈴木 醇教授還暦記念論文集

7）服部保正 (1962)：屈折波走時曲線の解析法につい ての研究, 地質工学 2

8）杉本卓司 (1972): 四国中央春梁山地飞おりる結晶 片岩の岩盤速度と地質構造, 地質工学 8

9）浅野周三 (1971): 日本列島の地殼構造の爆破地震 学的研究, 島弧と縁海

10）市川金德（1968）：水沢周辺地震探査について, UMP-A 帯連絡紙 No. 9

11) Masao GoraI (1963): Somc relations between the 
distribution of crustal thickness and fundamental geologic structure of Japanese Islands. Geophysical papers dedicated to prof. Kenzo SASSA

12) TAMAKI, I. (1961): Seismicity in relation to the crust structure, with special reference to Japanese area, MemOsaka Inst. Technology, Ser. A, 7

13) Matuzawa, T. (1959): On the crustal structure in northeast Japan by explosion seismic observations of the second Hokoda explosion, Bull. Earthq. Res. Inst. 37

14) Matuzawa, T. et al (1959): On the crustal structure derived from observations of the second Hokoda explosion, Bull. Earthq. Res. Inst. 37 